\title{
The Influence of Service Quality on Satisfaction: A Gender Comparison
}

\author{
Safiek Mokhlis ${ }^{1}$ \\ ${ }^{1}$ Faculty of Management and Economics, Universiti Malaysia Terengganu, Malaysia \\ Correspondence: Safiek Mokhlis, Faculty of Management and Economics, Universiti Malaysia Terengganu, \\ 21030 Kuala Terengganu, Malaysia. Tel: 609-668-4823. E-mail: safiek@umt.edu.my
}

Received: December 13, 2011

Accepted: December 31, $2011 \quad$ Published: October 18, 2012

doi:10.5539/par.v1n1p103

URL: http://dx.doi.org/10.5539/par.v1n1p103

\begin{abstract}
The purpose of this paper was to examine (1) the role of gender in predicting service quality perceptions and (2) the relationship between quality perceptions and satisfaction. The findings of this study were based on the empirical analysis of a sample of 234 respondents. Fifty three percent of the respondents $(n=124)$ were males while forty seven percent of the respondents were females $(n=110)$. The result generally support the hypothesis that gender affects service quality perceptions and the relative importance attached to dimensions of service quality. The study also revealed that that tangibles, reliability and responsiveness were critical service quality dimensions for determining satisfaction of both male and female customers.
\end{abstract}

Keywords: service quality, gender, municipality, perception, Thailand

\section{Introduction}

Revealing customer perceptions of service experiences has always been important to the success of all service organizations. From a management standpoint, managers should systematically examine current services from their customers' perspectives and redesign their service products and environment in which their services are delivered to their target customers (Rust \& Oliver, 1994). To provide quality experiences is extremely important for customer satisfaction and retention (Zeithaml, Bitner, \& Gremler, 2006). Service organizations providing public benefit services are no exception. Within the public service sector, offering superior quality and tailored services is a key contributor to customer satisfaction (Wisniewski, 2001).

The increasing number of academic publications devoted to such topics as service quality and customer satisfaction research represents the increased importance of services marketing and management (Asubonteng, McCleary, \& Swan, 1996; Ladhari, 2009). Although a substantial amount of research on service quality can be found in the marketing literature, little attention has been paid to the influence of gender on perceived service quality, with few exceptions. Previous research suggested gender affect perceptions of service quality due to gender role socialization, decoding ability, differences in information processing, traits, and the importance placed on core or peripheral services (Brody \& Hall, 1993; Dittmar, Long, \& Meek, 2004; Mattila, Gradey, \& Fisk, 2003). In marketing literature, studies showed that female customers tend to rate service quality lower when a comparison is made between genders (Lin, Chiu \& Shieh, 2001; Tan \& Kek, 2004; Snipes, Thomson \& Oswald, 2006; Juwaheer, 2011). However, the issue has not been examined in the context of local government services, particularly among customers of a municipal authority.

It is vitally important for municipal managers to understand potential gender effects in the evaluation of service quality for the development of effective marketing strategies. Investigating such relationships is significant, because without sound evidence and guidelines, managers may run the risk of making wrong decisions. On one hand, ignoring gender differences may create problems if there are gender-based differences. On the other hand, a gender-sensitive approach may become even more problematic if there are no differences between male and female customers (Karatepe, 2011). Thus, if the relative importance of the service quality dimensions to customers is likely to vary depending on their gender, resource allocation on those attributes should be contingent on the importance attached to them by customers. Therefore, in this study, the author investigated the relationships between service quality perceptions and satisfaction, with a focus on gender. Specific research questions include: (1) Are there any differences in the quality perceptions toward municipal services between male and female customers? and (2) What influence do the five service quality factors have on the customer 
satisfaction as perceived by each gender? As of yet, there is a dearth of empirical research on this issue. This study was an initial attempt to investigate the relationship between municipal service quality and customer satisfaction for each gender group in southern Thailand. Therefore, understanding the role of gender in service quality research can make both scientific and practical contributions.

This article is organized into five major sections. Following the introduction, background literature is presented. Subsequently, data and method, empirical analysis, results, discussion, and conclusions are offered.

\section{Literature Review}

\subsection{Service Quality}

Service quality is a concept that has attracted considerable interest and debate in the marketing literature because of the difficulties in both defining it and measuring it with no overall consensus emerging on either (Wisniewski, 2001). One that is commonly used defines service quality as the ability of the organization to meet or exceed customer expectations. It is the result of the comparison that customers make between their expectations about a service and their perception of the way the service has been performed (Zeithaml et al., 2006). If expectations are greater than performance, then perceived quality is less than satisfactory and hence customer dissatisfaction occurs (Parasuraman, Zeithaml \& Berry, 1985).

Most of the recent work on service quality in marketing can be credited to the pioneering and continuing work of Parasuraman, Berry and Zeithaml. In their seminal research study, Parasuraman et al. (1985) identified 97 attributes which were found to have an impact on service quality. These 97 attributes were the criteria that are important in molding customers' expectations and perceptions on delivered service. All these attributes fit into ten dimensions of service quality. These dimensions are: (1) tangible features, (2) reliability, (3) responsiveness, (4) communication, (5) credibility, (6) security, (7) competence, (8) courtesy, (9) understanding, and (10) access.

Later, these ten dimensions were purified into five by using factor analysis: tangibles, reliability, responsibility, assurance, and empathy (Parasuraman, Zeithaml, \& Berry, 1988). Based on these five dimensions, Parasuraman et al. (1988) developed a global measurement for service quality, namely, SERVQUAL. The scale consisted of 22 pairs of statements which measure customer expectations and perceptions of service delivered on a seven- or nine-point scale. For each pair of statements, the gap difference between the two scores is calculated. The idea is that the service is good if perceptions meet or exceed expectations and problematic if perceptions fall below expectations. The scale combined ten components into five generic dimensions of service quality (see Table 1).

Table 1. Five dimensions of service quality

\begin{tabular}{|c|c|}
\hline Dimension & Explanation \\
\hline Tangibles & $\begin{array}{l}\text { The appearance of physical facilities, equipment, personnel, and } \\
\text { communication materials. }\end{array}$ \\
\hline Reliability & The ability to perform the promised service dependably and accurately. \\
\hline Responsiveness & The willingness to help customers and provide prompt service. \\
\hline Assurance & $\begin{array}{l}\text { The knowledge and courtesy of employees and their ability to inspire trust and } \\
\text { confidence. }\end{array}$ \\
\hline Empathy & $\begin{array}{l}\text { The approachability, ease of access and effort taken to understand customers' } \\
\text { needs. }\end{array}$ \\
\hline
\end{tabular}

Since its inception, Parasuraman et al.'s (1988) SERVQUAL scale has become a popular method for measuring service quality (for a comprehensive review, see Asubonteng et al. 1996; Ladhari, 2009). The primary value of SERVQUAL lies in its powerful benchmarking, diagnostic, and prescriptive tools (Kettinger \& Lee, 1997). Notwithstanding its widespread impact on business and academia, SERVQUAL has been subjected to numerous criticisms, both the theoretical and operational aspects (Buttle, 1996). These criticisms include the use of gap scores, the overlap among five dimensions, length of the questionnaire, poor predictive and convergent validity, the ambiguous definition of the "expectation" construct, and unstable dimensionality (Carman, 1990; Babakus \& Boller, 1992; Cronin \& Taylor, 1992; Buttle, 1996). In response to critical SERVQUAL analysis, Cronin and Taylor (1992) introduced the SERVPERF instrument, based upon solely performance perception ratings. Studies have shown that SERVPERF instrument empirically outperforms the SERVQUAL scale across several service industries (e.g. Elliott, 1995; Van Dyke, Kappelman, \& Prybutok, 1997; Brady, Cronin, \& Brand, 2002; Paul, 
2003; Jain \& Gupta, 2004; Gilbert, Veloutsou, Goode, \& Moutinho, 2004).

\subsection{Gender and Service Quality Perceptions}

Marketers have traditionally used a variety of demographic variables to segment consumer markets such as income, age, gender, occupation, religion, ethnicity, education, marital status and household size. Demographics provide marketers with a means of determining which segments of the market are feasible in terms of achieving greater market penetration. Among these variables, gender continues to be one of the most common forms of segmentation used by marketers. Gender has been recognized as one of a small number of demographic variables that meets the basic requirements for successful implementation of segmentation strategies (Meyers-Levy \& Sternthal, 1991): (1) gender is easily identifiable; (2) gender segments are accessible (since most media provide this information) and (3) gender segments are large enough to be profitable.

Studies examining service quality in the marketing literature have given little consideration to identify gender differences in service quality evaluation. Previous research on gender effects on customer perceptions of service quality has produced somewhat conflicting results. For example, Stafford (1996) suggests service quality may be more important to women than to men when transacting business with a bank. In contrast, Snipes et al. (2006) found that male customers were more likely to rate the fairness and quality of service higher for given services when compared to their female counterparts. Spathis, Petridou and Glaveli (2004) found that male clients of Greek banks have a more positive perception of the quality of service they receive than do women clients. Also, there are several other examples in the marketing literature that indicate that female customers tend to rate service quality lower when comparison is made for both genders (Lin et al., 2001; Tan \& Kek, 2004; Juwaheer, 2011).

On the basis of the above discussion, the following hypothesis is proposed:

H1:Significant differences exist between male and female customers in their perceptions of municipal service quality.

\subsection{Perceived Service Quality and Satisfaction}

Customer satisfaction has been recognized as one of the most important elements of contemporary marketing thought, particularly in the case of service sectors (Bejou, Ennew \& Palmer, 1998) and one of the main goals in marketing (Erevelles \& Leavitt, 1992). Because satisfied customers tend to maintain their consumption pattern or consume more of the same product or service, customer satisfaction has become an important indicator of the future behavior (McQuitty, Finn \& Willey, 2000). Due to its centrality, various theories and models have been developed in an effort to define the construct and explain satisfaction in different products/services and consumption stages (for a review, see Erevelles \& Leavitt, 1992).

Marketing researchers are divided over the antecedents of service quality and satisfaction. Some scholars (e.g. Parasuraman et al., 1985, 1988) believe that service quality leads to satisfaction while others (e.g. Bolton \& Drew, 1991; Bitner \& Hubert, 1994) think otherwise. Empirical studies regarding this issue support the assertion that service quality is the antecedent of satisfaction (e.g. de Ruyter, Bloemer \& Pascal, 1997; Brady \& Robertson, 2001; Sureshchandar, Rajendran \& Kamalanabhan, 2001). Within this causal ordering, satisfaction is described as an emotional state resulting from experiencing a service quality encounter and comparing that encounter with what was expected (Zeithaml et al. 2006). Rust and Oliver (1994, p. 6) offer support for this position in their suggestion that quality is "one of the service dimensions factored into the consumers' satisfaction judgment". Previous studies conducted in different service settings have shown that perceived service quality is positively related to customer satisfaction (see, for example, Andaleeb, 2001; Lassar, Manolis, \& Winsor, 2000; Lee \& Lin, 2005). Thus, the following hypothesis is proposed:

$\mathrm{H} 2$ : There is a significant positive relationship between service quality and customer satisfaction.

\section{Methodology}

\subsection{Variable Measures}

The 22-item SERVQUAL scale that was designed by Parasuraman et al. (1988) was used in entirety in this study. Perceptions-only (P) score rather than gap score (P-E) was used since the perceptions only scale was the best measure when maximizing predictive power is the major objective (Parasuraman, Zeithaml, \& Berry, 1994). These items were measured on seven-point scale ranging from 1 (strongly disagree) to 7 (strongly agree). The score on each dimension is the mean of the sum of the corresponding item scores. To gather information about respondents' overall satisfaction with services provided by the municipal council, six statements adapted from Cronin and Taylor (1992) were used with reference to a 7-point rating scale $(1=$ very dissatisfied to $7=$ very 
satisfied).

\subsection{The Fieldwork}

For the purpose of this study, residents of Khok Pho municipality in Pattani Province, southern Thailand, were taken as study sample. The total number of household in Khok Pho is estimated at 558. According to the guidelines set by Krejcie and Morgan (1970), the required sample size for a population of 550 to 600 is 234 or $41.9 \%$ of the population. The survey was administered in February 2009 to a sample of 234 households with the help of three field assistants. From each household, only one individual, the head or the representative of the household was interviewed. The purpose of this was to avoid imitation or repetition of responses among the respondents and to obtain different views. Interviews were conducted by means of a structured questionnaire. The respondents were discreetly and politely approached with the purpose of the study being explained to them. The respondents were then asked if they would voluntarily participate in this study. If they were unable to participate due to time constraint, the researcher would approach them again at another time.

\section{Results}

\subsection{Sample Demographics}

The sample consisted of 234 respondents of which approximately half were males (53\%) and females (47\%), with the largest age group between 46 and 55 years old (34.6\%). Regarding the level of education, most of the respondents were primary school leavers $(38.5 \%), 30.3 \%$ had completed upper secondary level, $19.2 \%$ had a diploma and $12 \%$ had a graduate degree. The majority of respondents (35\%) reported income between 5,000 and 6,999 Bath per month. Finally, most of the people in the study were businessman (56\%) and farmers (22.6\%). Several also worked in the public sector (13.7\%) whereas only $7.3 \%$ were employees in the private sector.

\subsection{Dimensionality of Service Quality}

Exploratory factor analysis with principal component method was utilized in this study to extract a small number of latent variables (factors) from a large number of observed variables (22-items on the SERVQUAL). One critical assumption underlying the appropriateness of factor analysis is to ensure that the data matrix has sufficient correlations to justify its application. A first step is visual examination of the correlations, identifying those that are statistically significant. All correlations are above 0.3 , which is considered substantial for factor analysis (Hair, Anderson, Tatham \& Black, 1998). Furthermore, an inspection of the correlation matrix reveals that practically all correlations are significant at $\mathrm{p}<0.01$, and this certainly provides an excellent basis for factor analysis.

The next step involves assessing the overall significance of the correlation matrix with Bartlett test of sphericity, which provides the statistical probability that the correlation matrix has significant correlations among at least some of the variables. The results were significant at $p<0.001,\left(\chi^{2}=2589.24\right)$, which further confirmed that the data were suitable for factor analysis. Finally, Kaiser-Meyer-Olkin (KMO) measure of sampling adequacy was computed to quantify the degree of intercorrelations among the variables, and the results indicate an index of 0.88. Since a high-KMO value (close to 1.0) is achieved, the dataset is appropriate for factor analysis (Hair et al., 1998). As for the adequacy of the sample size, there is a 10-to-1 ratio of observations to variables in this study. According to Hair et al. (1998), the ratio for adequate sample size should be at least 10:1, which, in this case falls well within the acceptable limits.

Table 2 represents the final pattern matrix results of the factor analysis for the service quality dimensions. The analysis converged in sixteen iterations and resulted in five homogeneous sub-scales. The five factors were summarily named as follows: Empathy (5 items), Tangibility (5 items), Assurance (4 items), Reliability (4 items) and Responsiveness (4 items). The five factors, when added together, accounted for $67.77 \%$ of the variation in the data generated, which satisfies the percentage of variance criterion for social science research (Hair et al. 1998). Based on the factor structure, the convergent and discriminant validity of the five factors is good. The five factors extracted from the 22-item SERVQUAL are similar to the original study conducted by Parasuraman et al. (1988). Examining the individual items, only one out of the 22 items loaded incorrectly on the dimensions extracted in the study by Parasuraman et al. (1988).

Because the items comprising each factor were to be used in subsequent analysis, it was important to assess the internal consistency or reliability of those factors. Hence, a well-accepted measure of reliability, Cronbach's coefficient alpha, was computed for each of the five factors. The values of Cronbach's alpha lies between 0 and 1 , and the acceptable alpha value should be at least 0.7 (Hair et al. 1998). The results show that coefficient alphas for the five factors were in the range from 0.816 to 0.885 , implying high internal consistency reliability. 
Table 2. Factor analysis of service quality.

\begin{tabular}{lccccc}
\hline & \multicolumn{5}{c}{ Factor Loadings (Varimax rotation) } \\
\cline { 2 - 6 } Scale Items $^{\mathrm{a}}$ & Factor 1 & Factor 2 & Factor 3 & Factor 4 & Factor 5 \\
\hline Empathy 2 & 0.821 & 0.112 & 0.133 & 0.167 & 0.061 \\
Empathy 4 & 0.784 & 0.193 & 0.172 & 0.150 & 0.119 \\
Empathy 5 & 0.783 & 0.253 & 0.062 & 0.188 & 0.228 \\
Empathy 3 & 0.771 & 0.180 & 0.055 & 0.116 & 0.219 \\
Empathy 1 & 0.683 & 0.083 & 0.342 & 0.143 & 0.079 \\
Tangibility 1 & 0.129 & 0.809 & 0.075 & 0.147 & 0.175 \\
Tangibility 4 & 0.107 & 0.772 & 0.134 & 0.110 & 0.159 \\
Tangibility 3 & 0.143 & 0.751 & 0.105 & 0.066 & 0.153 \\
Reliability 1 & 0.218 & 0.747 & 0.132 & 0.135 & 0.063 \\
Tangibility 2 & 0.143 & 0.714 & 0.145 & 0.113 & 0.194 \\
Assurance 2 & 0.142 & 0.111 & 0.829 & 0.045 & 0.005 \\
Assurance 4 & 0.174 & 0.129 & 0.818 & 0.052 & 0.202 \\
Assurance 3 & 0.135 & 0.077 & 0.813 & 0.058 & 0.006 \\
Assurance 1 & 0.095 & 0.200 & 0.704 & 0.134 & 0.118 \\
Reliability 4 & 0.139 & 0.122 & 0.046 & 0.811 & 0.035 \\
Reliability 2 & 0.140 & 0.182 & 0.127 & 0.805 & 0.092 \\
Reliability 3 & 0.164 & 0.032 & 0.011 & 0.784 & 0.189 \\
Reliability 5 & 0.161 & 0.163 & 0.119 & 0.738 & 0.062 \\
Responsiveness 2 & 0.118 & 0.090 & 0.096 & 0.080 & 0.821 \\
Responsiveness 3 & 0.086 & 0.243 & 0.020 & 0.080 & 0.751 \\
Responsiveness 4 & 0.142 & 0.127 & 0.180 & 0.065 & 0.750 \\
Responsiveness 1 & 0.270 & 0.276 & 0.009 & 0.195 & 0.695 \\
\hline Eigenvalue & 2.190 & 2.037 & 1.722 & 1.540 \\
Total variance explained & $67.77 \%$ & 15.209 & 12.869 & 12.433 & 11.973 \\
Cronbach alpha & 0.865 & 0.843 & 0.835 & 0.816 \\
\hline
\end{tabular}

\subsection{Gender Differences in Service Quality Perceptions}

The first research question was: Are there any differences in the quality perceptions toward municipal services between male and female customers? To address this question, discriminate analysis was used to determine which service quality variables discriminate between male and female groups. The discriminant model developed in this study includes the service quality as the discriminating variables and gender of respondents (male versus female) as the categorical grouping variable. In the discriminant analysis used, mean differences and discriminant scores for male and female respondents were calculated for the service quality perceptions. Next, a multivariate discriminant analysis (MDA) was conducted both for description and prediction (hypothesis testing) purposes.

MDA is quite useful for evaluating differences among two or more groups in terms of specific attributes (Betz, 1987; Tabachnick \& Fidell, 2001). Tabachnick and Fidell (2001) suggested that MDA and related statistics are appropriate for describing group differences or predicting group membership on the basis of an independent variable while controlling for all other factors. A discriminant function score for a case is predicted from the sum of the series of predictors, each weighted by a coefficient (Tabachnick \& Fidell, 2001, p. 466). A maximum of $\mathrm{n}-1$ discriminant functions are nathematically possible when there are $\mathrm{n}$ groups. Since the present study involves a two-group discriminant analysis, only one canonical disriminant function is possible (Tabachnick \& Fidell, 2001). 
In Table 3, the means and standard deviations of respondents' scores on measures of perceived service quality are presented. In general the groups have different scores on each factor. Therefore, it may be expected that discrimination between men and women in terms of service quality perceptions will be found. In every instance, male respondents registered higher mean scores than their female counterparts.

Table 3. Means, standard deviations and mean difference of service quality perceptions

\begin{tabular}{lccccc}
\hline \multirow{2}{*}{ Factor } & \multicolumn{2}{c}{ Male $(\mathrm{n}=124)$} & \multicolumn{2}{c}{ Female $(\mathrm{n}=110)$} & $\begin{array}{c}\text { Mean } \\
\text { difference }\end{array}$ \\
\cline { 2 - 5 } & Mean & S.D. & Mean & S.D. & 0.521 \\
\hline Empathy & 4.274 & 1.133 & 3.753 & 1.105 & 0.368 \\
Tangibles & 4.431 & 1.041 & 4.073 & 0.963 & 0.102 \\
Assurance & 3.716 & 1.137 & 3.614 & 1.090 & 0.284 \\
Reliability & 4.377 & 1.069 & 4.093 & 0.965 & 0.194 \\
Responsiveness & 3.837 & 0.949 & 3.643 & 0.987 & \\
\hline
\end{tabular}

Table 4 displays the summary of interpretive measures for discriminate analysis. The discriminant function developed in this study has a chi-square value of 15.452 ( 5 degrees of freedom) which is significant at $p<0.01$ level. This provides strong discriminate group membership on the basis of the variables used. Thus, Hypothesis 1 was supported. With a canonical correlation of 0.255 , it can be concluded that $6.5 \%$ (square of the canonical correlation) of the variance in the dependent variable was accounted for by this model.

To test which of the service quality factors is best at discriminating between the groups, the discriminant loadings (within group correlation) was examined. This is because the discriminant loadings is unaffected by co linearity unlike the standardized coefficients which can inflate the discriminating ability of the variable. Table 4 shows that Empathy had the highest value $(0.884, \mathrm{p}<0.01)$, which means it best discriminates between males and females. This is followed by Tangibles $(0.676, \mathrm{p}<0.01)$ and Reliability $(0.528, \mathrm{p}<0.05)$. Thus the discriminate function from Table 4 can be written mathematically below as:

$$
d_{i k}=-3.991+0.804 \text { (Empathy) }+0.444 \text { (Tangibles) }+0.17 \text { (Reliability) }
$$

Table 4. Summary of interpretive measures for discriminate analysis

\begin{tabular}{lcccc}
\hline Independent variable & $\begin{array}{c}\text { Unstandardized } \\
\text { CDFC }\end{array}$ & $\begin{array}{c}\text { Standardized } \\
\text { CDFC }\end{array}$ & $\begin{array}{c}\text { Discriminant } \\
\text { loading (rank) }\end{array}$ & $\begin{array}{c}\text { Univariate } \\
\text { F-ratio }\end{array}$ \\
\hline Empathy & 0.718 & 0.804 & $0.884(1)$ & $12.637 * * *$ \\
Tangibles & 0.442 & 0.444 & $0.676(2)$ & $7.389 * *$ \\
Assurance & -0.271 & -0.303 & $0.174(5)$ & 0.488 \\
Reliability & 0.166 & 0.170 & $0.528(3)$ & $4.501 *$ \\
Responsiveness & -0.132 & -0.128 & $0.380(4)$ & 2.333 \\
\hline Functions at group cancroids: & \multicolumn{4}{l}{ Wilks lambda } \\
Male & 0.247 & Canonical correlation & 0.935 \\
Female & -0.279 & (Canonical correlation) & 0.255 \\
\hline
\end{tabular}

Description: Box M's test was not statistically significant (Box's $M=16.747, p<0.359$ ), indicating equality of group covariance matrices.

$\mathrm{CDFC}=$ Canonical discriminate function coefficients

*** significant at $\mathrm{p}<0.001 ; * *$ significant at $\mathrm{p}<0.01 ; *$ significant at $\mathrm{p}<0.05$

Results concerning the accuracy of the discriminate procedure and the degree of group separation are presented by the cross-tabulation shown in Table in Table 5. As shown in the table, the function resulted in correct predictions being made for $58.5 \%$ of the subjects; $57.3 \%$ of men and $42.7 \%$ of women were correctly classified. 
Two criteria can be used to judge how good the hit rate is, i.e. to judge the goodness of classification accuracy. They are the maximum chance criterion and the proportional chance criterion (Betz, 1987). The maximum chance criterion classifies any case chosen at random into the larger group, to maximize the proportion of cases correctly classified. The sample for this study consists of 110 cases in the female group and 124 in the male group. Classifiying all cases into the larger group yields classification accuracy of $124 / 234,53 \%$. The discriminant model's classification accuracy of $58.5 \%$ is 5.5 points better than that of the maximum chance model. The proportional chance criteria for assessing model fit is calculated by summing the squared proportion that each group represents of the sample. Using the probabilities from the output 'Prior Probabilities for Groups', the calculation in this case is $(0.5 \times 0.5)+(0.5 \times 0.5)=50 \%$. The discriminant model's classification accuracy is 8.5 points better.

Table 5. Classification matrix for discriminant function

\begin{tabular}{llccc}
\hline \multirow{2}{*}{ Actual group } & \multicolumn{2}{c}{ Predicted group } & \multirow{2}{*}{ Total } \\
\cline { 2 - 3 } & & Male & Female & \\
\hline Male & Count & 71 & 53 & 124 \\
& $\%$ & 57.3 & 42.7 & 53 \\
Female & Count & 44 & 66 & 110 \\
& $\%$ & 40 & 60 & 47 \\
Total & Count & 115 & 119 & 234 \\
& $\%$ & 49.1 & 50.9 & 100 \\
\hline Overall percentage of cases correctly classified by discriminate function: & $58.5 \%$ \\
Percentage accuracy based on maximum chance criterion: & $53 \%$ \\
Percentage accuracy based on proportional chance criterion: & $50 \%$ \\
\hline
\end{tabular}

\subsection{Predictability of Service Quality to Satisfaction}

The second research question was: What influence do the five service quality factors have on the customer satisfaction as perceived by each gender? A standard multiple regression analysis was performed to examine the relationship between the dimensions of service quality and customer satisfaction. Additionally, regression coefficients were used to identify service quality factors that influence customer satisfaction for each gender. The regression model considered customer satisfaction to be the dependent variable and the five dimensions of service quality to be independent variables. Tolerance statistics were computed on each variable in order to determine if multicollinearity existed among the predictor variables. The results of the tolerance statistics indicated that the tolerance was at or greater than 0.524 (range $0.524-0.793$ for male; and $0.76-0.831$ for female), indicating no evidence of multicollinearity problems for any of the predictor variables.

In Table 6, the results of the regression coefficients and R-square for each gender revealed that significant influences of service quality factors on customer satisfaction existed for each gender. The regression models for each of the gender groups were statistically significant (see Table 5). Therefore, Hypothesis 2 was supported.

The five factors of service quality collectively explained a total of $48.1 \%$ variance on the customer satisfaction for males $\left(\mathrm{R}^{2}=0.481\right)$. Three dimensions of service quality showed a statistically significant and unique relationship with customer satisfaction for male customers. The dimensions of Tangibles $(\beta=0.282, p<0.001)$ indicated the strongest influences over customer satisfaction, followed by Reliability $(\beta=0.224, p<0.01)$ and Responsiveness $(\beta=.197, \mathrm{p}<0.05)$.

The five factors of service quality collectively explained a total of $53.8 \%$ variance on the customer satisfaction for females $\left(R^{2}=0.538\right)$. Further, the regression coefficients indicated that the dimensions of Tangibles $(\beta=$ $0.348, p<0.001)$ and Reliability $(\beta=0.373, p=0.001)$ exerted statistically significant influence on overall customer satisfaction, followed by the dimension of Responsiveness $(\beta=0.156, \mathrm{p}<0.05)$. 
Table 6. Influence of the five service quality factors on satisfaction.

\begin{tabular}{lcc}
\hline & \multicolumn{2}{c}{ Customer satisfaction } \\
\cline { 2 - 3 } Predictors & Male $(\beta)$ & Female $(\beta)$ \\
\hline Empathy & 0.151 & 0.105 \\
Tangibles & $0.282^{* * *}$ & $0.348^{* * *}$ \\
Assurance & 0.117 & 0.077 \\
Reliability & $0.224^{* *}$ & $0.373^{* * *}$ \\
Responsiveness & $0.197^{*}$ & $0.156^{*}$ \\
\hline Adjusted $\mathrm{R}^{2}$ & 0.481 & 0.538 \\
F-value & $23.776^{* * *}$ & $26.131^{* * *}$ \\
\hline Description: $\beta=$ standardized beta coefficients; *** $\mathrm{p}<0.001 ;$ \\
$* * \mathrm{p}<0.01 ; * \mathrm{p}<0.05$
\end{tabular}

\section{Conclusions}

Analysis of the data collected answered the study's hypotheses with robust statistical significance, contributing to the collective body of knowledge about gender, customer satisfaction, and the five service quality determinants identified by Parasuraman et al. (1988) within the context of public service organization. The findings indicate that the five service quality dimensions identified in this specific study similar in number and dimensional structure from the widely adopted service quality dimensions first identified by Parasuraman et al. (1988). For three of the factors, namely empathy, tangibles, and reliability, gender discriminated significantly, with male customers attaching greater importance to these factors than did female customers. Only two of the factors, assurance and responsiveness, seem equally important to both sexes. The study also revealed that service quality has a positive relationship with customer satisfaction. Three service quality factors were found to significantly predict customer satisfaction, namely tangibles, reliability and responsiveness.

Findings from this study provide useful insights for municipal management to identify their customers' wants, take action to improve service delivery, and establish standards of performance to address the identified customers' needs. Differences between the responses of male and female customers should send a clear message to municipal managers that they are dealing with two distinct customer segments, and these differences need to be taken into account if they want to enhance customers' perceptions of service quality. Knowing that two of the five service quality dimensions were not statistically positively correlated with satisfaction for the population as a whole can help municipal managers avoid unnecessary and expensive programs that may have focused on the lesser important dimensions. By concentrating on those service quality dimensions weighted most significant to both gender groups, municipal managers can make better informed decisions regarding the allocation of expenditures for physical appearance, upgrades and improvements, personnel, and training programs.

In spite of the fact that findings from this research do contribute to the existing body of knowledge about customer satisfaction within public service organization, there were several limitations of the study that should be taken into account when interpreting the results. In a strict sense the results pertain only to the respondents and generalizations to a wider population or service sector should be done with caution. The sample size was not large but adequate for the type of analysis undertaken. Further, gender is not the only characteristic on which marketing efforts should be based. Therefore, other demographic variables, such age, religion, education level, and income must be considered when developing marketing strategies. Certainly, the better that municipal organizations understand their customers and what is important to those customers in terms of service quality, the better the organizations will be at providing the proper levels of service quality.

\section{References}

Andaleeb, S. S. (2001). Service quality perceptions and patient satisfaction: A study of hospitals in a developing country. Social Science \& Medicine, 52(9), 1359-1370. http://dx.doi.org/10.1016/S0277-9536(00)00235-5

Asubonteng, P., McCleary, K. J., \& Swan, J. E. (1996). SERVQUAL revisited: A critical review of service quality. Journal of Services Marketing, 10(6), 62-81. http://dx.doi.org/10.1108/08876049610148602

Babakus, E., \& Boller, G. W. (1992). An empirical assessment of the SERVQUAL scale. Journal of Business Research, 24, 253-268. http://dx.doi.org/10.1016/0148-2963(92)90022-4 
Bejou, D., Ennew, C. T. \& Palmer, A. (1998). Trust, ethics and relationship satisfaction. International Journal of Bank Marketing, 15(3), 73-82. http://dx.doi.org/10.1108/02652329810220729

Betz, N. E. (1987). Use of discriminant analysis in counseling psychology research. Journal of Counseling Psychology, 34(4), 393-403. http://dx.doi.org/10.1037/0022-0167.34.4.393

Bitner, M. J., \& Hubbert, A. R. (1994), Encounter satisfaction versus overall satisfaction versus quality: The consumer's voice. In R. T. Rust \& R. L. Oliver (Eds.), Service quality: new directions in theory and practice (pp. 72-94). Thousand Oaks, CA: Sage Publications.

Brady, M. K., Cronin, J. J., \& Brand, R. R. (2002). Performance-only measurement of service quality: A replication and extension. Journal of Business Research, 55(1), 17-31. http://dx.doi.org/10.1016/S0148-2963(00)00171-5

Brady, M. K. \& Robertson, C. J. (2001). Searching for a consensus on the antecedent role of service quality and satisfaction: An exploratory cross-national study. Journal of Business Research, 51(1), 53-60. http://dx.doi.org/10.1016/S0148-2963(99)00041-7

Bolton, R. N., \& Drew, J. H. (1991). A multistage model of consumers' assessments of service quality and value. Journal of Consumer Research, 17, 375-384. http://dx.doi.org/10.1086/208564

Brody, L., \& Hall, J. A. (1993). Gender and emotion. In M. Lewis, \& J. Haviland (Eds.), Handbook of emotions (pp. 447-460). New York, NY: Guilford Press.

Buttle, F. (1996). SERVQUAL: Review, critique, research agenda. European Journal of Marketing, 30(1), 8-32. http://dx.doi.org/10.1108/03090569610105762

Carman, J. M. (1990). Consumer perceptions of service quality: An assessment of SERVQUAL dimensions. Journal of Retailing, 66(1), 33-55.

Cronin, J. J., \& Taylor, S. A. (1992). Measuring service quality: A reexamination and extension. Journal of Marketing, 56(3), 55-68. http://dx.doi.org/10.2307/1252296

de Ruyter, K., Bloemer, J., \& Peeters, P. (1997). Merging service quality and service satisfaction. An empirical test of an integrative model. Journal of Economic Psychology, 18(4), 387-340. http://dx.doi.org/10.1016/S0167-4870(97)00014-7

Dittmar, H., Long, K., \& Meek, R. (2004). Buying on the internet: Gender differences in online and conventional buying motivations. Sex Roles, 50(5/6), 423-444. http://dx.doi.org/10.1023/B:SERS.0000018896.35251.c7

Elliott, K.M. (1995). A comparison of alternative measures of service quality. Journal of Customer Service in Marketing and Management, 1(1), 33-44. http://dx.doi.org/10.1300/J127v01n01_04

Erevelles, S., \& Leavitt, C. (1992). A comparison of current models of consumer satisfaction/dissatisfaction. Journal of Satisfaction, Dissatisfaction and Complaining Behavior, 5, 104-114.

Gilbert, G. R., Veloutsou, C., Goode, M. M. H., \& Moutinho, L. (2004). Measuring customer satisfaction in the fast food industry: a cross-national approach. Journal of Services Marketing, 18(5), 371-383. http://dx.doi.org/10.1108/08876040410548294

Hair, J. F., Anderson, R., Tatham, R., \& Black, W. C. (1998). Multivariate Data Analysis (5th ed.). Upper Saddle River, NJ: Prentice Hall.

Jain, S. K., \& Gupta, G. (2004). Measuring service quality: SERVQUAL vs. SERVPERF scales. Vikalpa, 29(2), 25-37.

Juwaheer, T. D. (2011). Gender bias in hotel guests' perceptions of service quality: an empirical investigation of hotels in Mauritius. e-Review of Tourism Research, 9(5), 164-189.

Karatepe, O. M. (2011). Service quality, customer satisfaction and loyalty: the moderating role of gender. Journal of Business Economics \& Management, 12(2), 278-300.

Kettinger, W. J., \& Lee, C. C. (1997). Pragmatic Perspectives on the measurement of information systems service quality. MIS Quarterly, 21(2), 223-240. http://dx.doi.org/10.2307/249421

Krejcie, R. V., \& Morgan, D. W. (1970). Determining sample size for research activities. Educational and Psychological Measurement, 30(3), 607-610.

Ladhari, R. (2009). A review of twenty years of SERVQUAL research. International Journal of Quality and Service Sciences, 1(2), 172-198. http://dx.doi.org/10.1108/17566690910971445 
Lassar, W. M., Manolis, C., \& Winsor, R. D. (2000). Service quality perspectives and satisfaction in private banking. Journal of Services Marketing, 14(3), 244-271. http://dx.doi.org/10.1108/08876040010327248

Lee, G. G., \& Lin, H. F. (2005). Customer perceptions of e-service quality in online shopping. International Journal of Retail \& Distribution Management, 33(2), 161-176. http://dx.doi.org/10.1108/09590550510581485

Lin, N. P., Chiu, H. C., \& Hsieh, Y. C. (2001). Investigating the relationship between service providers' personality and customers' perceptions of service quality across gender. Total Quality Management, 12(1), 57-67. http://dx.doi.org/10.1080/09544120020010093

Mattila, A. S., Gradey, A. A., \& Fisk, G. M. (2003). The interplay of gender and affective tone in service encounter satisfaction. Journal of Service Research, 6(2), 136-143. http://dx.doi.org/10.1177/1094670503257043

McQuitty, S., Finn, A., \& Wiley, J. B. (2000). Systematically varying consumer satisfaction and its implications for product choice. Academy of Marketing Science Review, 2000(10), 1-16.

Meyers-Levy, J., \& Sternthal, B. (1991). Gender differences in the use of message cues and judgments. Journal of Marketing Research, 28(1), 84-96. http://dx.doi.org/10.2307/3172728

Parasuraman, A., Zeithaml, V., \& Berry, L. (1985). A conceptual model of service quality and its implications for future research. Journal of Marketing, 49, 41-50. http://dx.doi.org/10.2307/1251430

Parasuraman, A., Zeithaml, V., \& Berry, L. (1988). SERVQUAL: a multiple item scale for measuring consumer perceptions of service quality. Journal of Retailing, 64(1), 12-40.

Parasuraman, A., Zeithaml, V. A., \& Berry, L. L. (1994). Reassessment of expectations as a comparison standard in measuring service quality: implications for further research. Journal of Marketing, 58(1), 111-124. http://dx.doi.org/10.2307/1252255

Paul, D. P. (2003). An exploratory examination of "SERVQUAL" versus "SERVPERF" for prosthetic dental specialists. Clinical Research and Regulatory Affairs, 20(1), 89-100. http://dx.doi.org/10.1081/CRP-120018745

Rust, R. T., \& Oliver, R. L. (1994). Insights and managerial implications from the frontier. In R.T. Rust and R. L. Oliver (Eds.), Service quality: new directions in theory and practice (pp.1-19). Thousand Oaks, CA: Sage.

Snipes, R. L., Thomson, N. F., \& Oswald, S. (2006). Gender bias in customer evaluations of service quality: An empirical investigation. Journal of Service Marketing, 20(4), 274-284. http://dx.doi.org/10.1108/08876040610674616

Spathis, C., Petridou, E., \& Glaveli, N. (2004). Managing service quality in banks: customers' gender effects. Managing Service Quality, 14(1), 90-102. http://dx.doi.org/10.1108/09604520410513695

Stafford, M. R. (1996). Demographic discriminators of service quality in the banking industry. Journal of Services Marketing, 10(4), 6-22. http://dx.doi.org/10.1108/08876049610124554

Sureshchandar, G. S., Rajendran, C., \& Kamalanabhan, T. J. (2001). Customer perceptions of service quality: A critique. Total Quality Management, 12(1), 111-124. http://dx.doi.org/10.1080/09544120020010138

Tabachnick, B. G., \& Fidell, L. S. (2001). Using multivariate statistics. Boston, MA: Allyn and Bacon.

Tan, K. C., \& Kek, S. W. (2004). Service quality in higher education using an enhanced SERVQUAL approach. Quality in Higher Education, 10(1), 17-24. http://dx.doi.org/10.1080/1353832242000195032

Van Dyke, T. P., Kappelman, L. A., \& Prybutok, V. (1997). Measuring information systems service quality: Concerns on the use of the SERVQUAL questionnaire. MIS Quarterly, 21(2), 195-208. http://dx.doi.org/10.2307/249419

Van Ryzin, G. G. (2004). The measurement of overall citizen satisfaction. Public Performance and Management Review, 27(3), 9-28.

Wisniewski, M. (2001). Using SERVQUAL to assess customer satisfaction with public sector services. Managing Service Quality, 11(6), 380-388. http://dx.doi.org/10.1108/EUM0000000006279

Zeithaml, V. A., Bitner, M. J., \& Gremler, D. D. (2006). Service marketing: Integrating customer focus across the firm (4th ed.). New York, NY: McGraw-Hill/Irwin. 